\title{
Investigating the Factors that Enhance Tourists' Intention to Revisit Touristic Cities. A Case Study on Luxor and Aswan in Egypt
}

\author{
Hussein Magdy Hussein ${ }^{*} \quad$ Eman Mohamed Abdel Salam ${ }^{2} \quad$ Hazem Rasheed Gaber $^{3}$ \\ Arab Academy for Science, Technology and Maritime Transport, Alexandria, Egypt
}

\begin{abstract}
This article examines the impact of some factors that enhance tourists' revisit intention to touristic cities. It adopts the TPB to predict tourists' intention to revisit these destinations. An online the questionnaire was utilized to collect data from tourists that have earlier visited two touristic cities in Egypt which are Luxor and Aswan. The responses of 373 visitors to Luxor and Aswan were analyzed and the proposed hypotheses were evaluated using the Structural Equation Modeling (PLS-SEM). The results show that the model has a strong explanatory power to understand travelers' revisit intention. Besides the TPB infrastructure, the added variables were found to exert a significant influence on the revisit intention. Specifically, the results show that: (1) e-WOM positively influences tourists' attitudes and perceived behavioral control and subjective norms (2) tourist's satisfaction positively influences tourists' revisit intention and e-WOM (3) perceived behavioral control positively influences tourists' revisit intention. The paper offers to the academic literature by implementing a framework that explains tourists' intention to revisit the touristic cities. Also, it provides practitioners who are interested in tourism marketing with some guidelines to follow to enhance the revisit intention of tourists.
\end{abstract}

Keywords: Revisit intention, Touristic cities, e-WOM, Theory of planned behavior

DOI: $10.7176 / \mathrm{JAAS} / 69-04$

Publication date:October $31^{\text {st }} 2020$

\section{Introduction}

Tourism is the fastest growing industry in the world today, offering many developing countries new job opportunities and an significant source of foreign currency income, as the tourism industry has become more competitive and globalized due to technological advances in information and communications according world tourism organization (UNWTO Tourism highlights 2018). In 2018 there were 1.326 billion international tourists with a total turnover of 1.340 trillion dollars. It constitutes about $10 \%$ of global GDP, with tourism generating more than 266 million direct and indirect jobs worldwide accounting for $30 \%$ of global service exports (UNWTO, 2018).

Egypt is one of the major destinations in the Middle East (Avraham, 2016). Tourism is one of the main economic contributors and a potential development mechanism. This also contributes about $20 \%$ of annual GDP to countries (Forum, 2019). Egypt is an outstanding history, which dates back over 7,000 years, as well as the presence of seven archeological sites across the land, as a World Heritage Site for the ancient Coptic and Islamic and Egyptian archeological sites. The aim to represent was highlighted in the competition market for tourist destinations as an important research subject. Although, there are a large number of researches on travel Tourists, there is still a research gap between the intention to re-visit, e-WOM, tourist satisfaction and TPB (Puad et al., 2012).

Egypt, moreover, possesses an ancient cultural and historical heritage and offers the atmosphere of attractive sea surrounding the east and north Mediterranean's on the sides of the Red Sea and making Egypt the only place that many generations of tourists worldwide must visit (Avraham, 2016). Moreover, Egypt also enjoys competitive prices among many destinations in the world, which increases Egypt's share in global tourism according to the 2018 Tourism and Travel Competitiveness Index, Egypt ranks second globally according to competitive pricing standards (Forum, 2019).

Luxor and Aswan are considered one of the large famous centers in the world as it contains many historical sources (Kamar, 2014). It has one-sixth of the world's monuments and a third of Egypt's monuments (Forum, 2019). Travel agencies market and implement several historical tourism programs. Luxor and Aswan are characterized by many tourist attractions and destinations that have made them unique around the world, especially in the winter season, characterized by a moderate climate due to its location on the Nile.

Egypt is one of the main donor countries to the Egyptian economy in 2010 (Forum, 2019). However, the covid-19 came in 2020, which affected the closure of tourism all over the world, which had a negative effect on Egypt's tourism sectors due to fears of the pandemic. Egyptian tourism has also been reported to decline after the revolution during 2011 due to political indecision and safety problems and the pressure from neighborhoods like Morocco, Tunisia and Turkey. Thus, in 2012 to 2017, the number of foreign tourists declined considerably in Egypt to record almost 9 million tourists per year, with the tourist population reaching more than 14.7 million in 
2010 ( UNWTO, 2018). Also, declined from 10 centers in the world ranking of the Competitiveness Index for Tourism and Travel for the year 2018, ranking 74 globally in 2018 after ranking 64 globally in 2010 (Forum, 2019).

In many previous studies, the TPB model was obviously widely applied. However, the approaches and intentions of tourists are applied in the study (Lam and Hsu, 2004). According to Bianchi, Milberg and Cúneo (2017), Specific Research used this method to predict the intention of tourists to choose a destination. Therefore, the expanded TPB model consists of the frameworks studied which influence the Luxor and Aswan reconsideration intentions. The current research therefore aims to (a) to clarify the relationship between e-WOM and TPB on the plan for tourists to return to Luxor and Aswan. (b) Explore the relationship between the satisfaction of tourists and their revisit intention.

\section{The proposed model}

The proposed model was based on the literature and included five predictive variables: the e-WOM and the perceived behavioral influence and the subjective expectations and attitudes to a destination and the satisfaction of tourism. Each variable had a direct connection with the intention to revisit.

Figure 1. hypotheses and Conceptual model

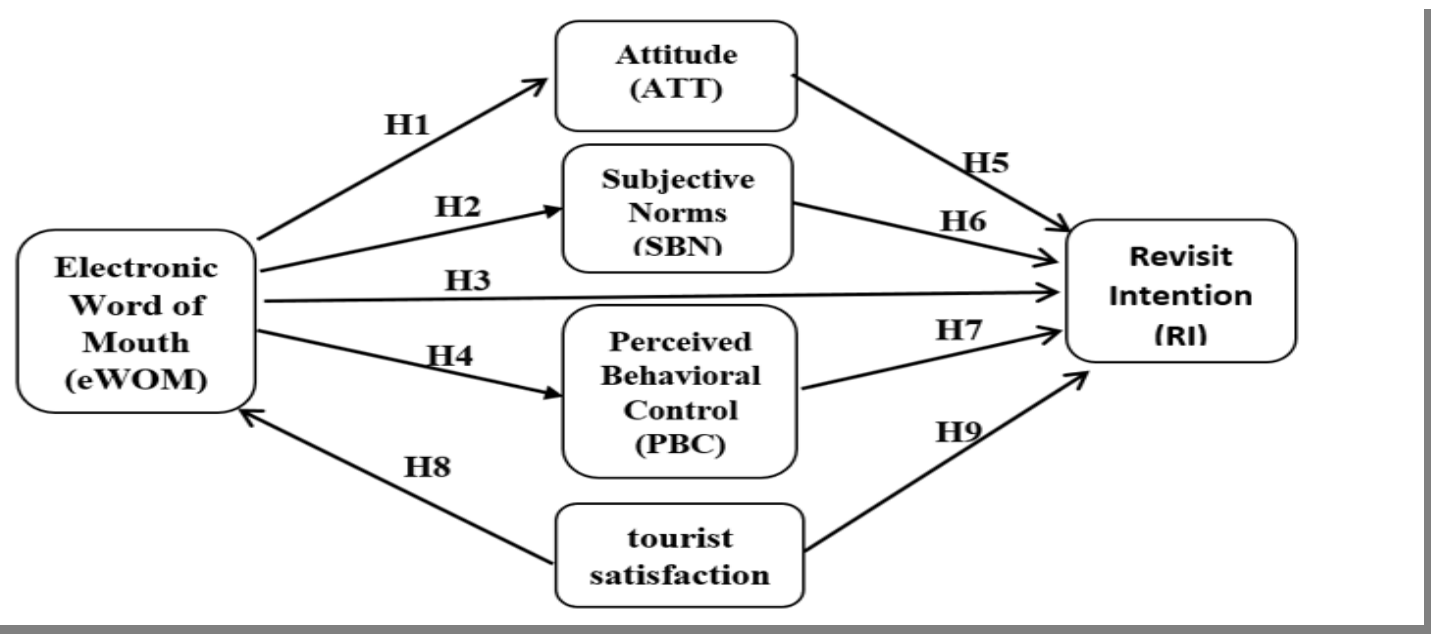

\section{Literature review. Conceptual development and hypotheses}

\section{$3.1 e-W O M$}

Electronic mouth is one of the leading information and data outlets for customers in the IT world (Lee, Park and Han, 2008). E-WOM thus refers to a very casual way of exchanging interactions with others about services or goods (Cheung and Lee, 2012). Through internet technology development, the number of tourists using the internet to find information and make online bookings for tourist destinations is growing. E-WOM is an convenient way for Tourists to learn about destinations (Ladhari and Michaud, 2015). E-WOM communicates in so many ways, example, website, twitter, Facebook, Instagram, and platform with web-based. This has revolutionized the distribution and impact of e-WOM on tourists (Jalilvand, Ebrahimi and Samiei, 2013).

The main relationship between TPB and e-WOM was discussed (Jalilvand and Samiei, 2012). E-WOM has been found to be a primary source of data for travelers and affects their actions significantly. Positive e-WOMs affect tourism attitudes to the destination. According to Lai Ying and Chung (2007), E-WOM also showed that it has an significant, positive effect on tourism towards the destination (Jalilvand and Samiei, 2012).

In a study by Llodrà-Riera et al. (2015) revealed 541 Mallorca tourists, indicating that websites, which the user creates in online sharing, exert effects and merge to form a source of information on tourist destinations. In fact, they have shown that website users who post tourist information have valuable online content that offers usergenerated content when seeking information about a tourist destination they visit and what other people say. However, a research carried out by 168 travelers. Also, in a study by Vermeulen and Seegers (2009) has shown that constructive reviews boost the attitudes of Tourists towards destinations and hotels in order to ascertain the effect of online feedback on their attitude towards them.(Reza Jalilvand et al., 2012;Jalilvand, Ebrahimi and Samiei, 2013) found that E-WOM is an effective tourism source, affecting significantly subjective norms and destination attitudes e-WOM. Moreover, revealed an important relationship between e-WOM and subjective norms (Jalilvand and Samiei, 2012)

Based on the above, e-WOM has a strong effect on social expectations and attitudes towards perceived behavioral control, according to previous research (Reza Jalilvand et al., 2012; Jalilvand and Samiei, 2012; Jalilvand, Ebrahimi and Samiei, 2013), They suggested that e-WOM is strongly and specifically related to behavioral regulation according to Cheng, Lam and Hsu, (2006a) As a result, it was shown that information on e- 
WOMs would influence tourist attitudes (Palka, Pousttchi and Wiedemann, 2009). Thus, based on previous research, eWOM has a clear and positive effect on social expectations and perceived behavioral regulation. Therefore, the first, second and third results of this review are:

H1. E-WOM has a significant effect on tourists' attitudes toward a destination.

H2. E-WOM has a significant effect on subjective-norms.

H3. E-WOM has a significant effect on perceived behavioral control.

In this study, e-WOM is selected as sources of information which may effect for reasons on the tourist's intention to revisit. Secondly, e-WOM offers tourist information such as information resources, rates, booking methods, social networks and accessibility. E-WOM is therefore a special source of research deserving of knowledge (Luo and Zhong, 2015). Second, several scholars believed that e-WOM is a source of knowledge that could be downplayed by other outlets (Baber et al., 2016).

Therefore, e-WOM has a strong effect on intention to revisit (Jalilvand, Ebrahimi and Samiei, 2013). If visitors are satisfied by their experience, the effects of these investigations are expected to recommend this information to the complete network intended for visiting another tourist (Liu and Lee, 2016). Also, e-WOM may also effect an increasing number of tourists who visit an appropriate location, because they will revisit this destination for details (Litvin, Goldsmith and Pan, 2008).

Past researchers have discovered that e-WOM has a major influence on the visitor's intention to visit the destination (Jalilvand and Samiei, 2012; Mohammed Abubakar, 2016). Additionally, Abubakar et al., (2017) explained that the traveler's intention to visit the context of medical tourism is very affected by e-WOM. Consequently, e-WOM has a direct and decisive influence on visitors aim to revisit (Jalilvand, Ebrahimi and Samiei, 2013; Luo and Zhong,2015; Abubakar, Ilkan and Sahin, 2016). The decision of tourists to revisit a destination indicates how tourists feel at certain times so that they can build the perception of tourists to visit again. Shown research has on e-WOM and the tourist's intention to revisit the decision demonstrated that online communication has a positive influence on the traveler's intention to revisit again (Matute, Polo-Redondo and Utrillas, 2016). Thus, the fourth hypothesis of this research is proposed as follows:

\section{H4. E-WOM has a significant impact on revisit intention.}

\section{$3.2 T P B$}

TPB is a general conduct system used in research on tourism and earlier studies that predict a sequence of behavioral intentions (Han, Hsu and Sheu, 2010; Hsu and Huang, 2012; Reza Jalilvand et al., 2012). The theory notes that behavioral intent is based on behavioral behaviors, and behavioral regulation and subjective standards (Ajzen, 1991). Attitude requires a certain form of actions, including negative and positive feelings. In particular, "the level to which a person has a positive or negative assessment or assessment of the behavior concerned" is defined in the position (Ajzen, 1991). Subjective norms refer to a social factor that includes perceived social pressures to achieve or not achieve particular behavior. Cognitive-behavioral control represents an individual's perception of his or her ability to perform a particular job.

There is now strong support to using this psychosocial model (Castro, Martín Armario and Martín Ruiz, 2007). New experimental studies have reached a broad understanding that expanding a TPB in a specific tourist context appears to be a crucial process for a better perception of behavioral intentions toward specific destination sites (Yuzhanin and Fisher, 2016) .

Subjective expectations demonstrate lack of conduct and a propensity to respond to this stress (Ajzen and Fishbein, 1980; Moutinho, Ballantyne and Rate, 2011). It is believed that subjective norms are a function of a person's understanding that others understand the reference and motivating behavior to meet these reviewers' convictions and expectations (Ajzen and Fishbein, 1980). The goal is behavioral regulation that shows human understanding of its ability to function (Ajzen, 1991). Reflexology deals with the requisite tools and incentives for conduct.

Perceptive behavioral control plays a major part in general behavior. Perceived behavioral control indicates how easily or hard an individual understands to behave in a particular way(Ajzen and Madden, 1986). Conducted research using TPB to predict the intentions of visiting green hotels for young consumers and discovered that the intention was positively affected by perceived behavioral control towards green hotel visits (Verma and Chandra, 2018). Thus, many experimental investigations conducted to prognosticate behavioral the intention by the use of TPB indicate that the positive relationships between the perceived behavioral control and tourists' intention to revisit.

Early studies in tourism suggest that the situation can be an important factor prophesies and describes the effect visitors intentions (Bianchi, Milberg and Cúneo, 2017; Han and Kim, 2010) to work on specific behaviors such as visiting the destination (Huang and Hsu, 2009). Subjective standards and perceived behavioral control too have a positive influence on the present visiting behavior of individuals(Chen and Tung, 2014; Han and Kim, 2010; Hsu and Huang, 2012). (Lam and Hsu, 2004;Cheng, Lam and Hsu, 2006a) revealed that increased preferred posture, perceived behavioral control and subjective norms will lead to an increase in endurance to visit a destination. 
Furthermore, a study (Han and Kim, 2010) showed that the reconsideration of intent is absolutely and significantly correlated with the infrastructure of the TPB model position, perceived behavioral control and subjective norms . The fifth and sixth and seventh hypotheses of this research were suggested as follows:

H5. Attitudes toward a destination have a significant effect on tourists' intention to revisit. H6. Subjective norms have a significant effect on tourists' intention to revisit.

H7. Perceived behavioral control has a significant effect on tourists' intention to revisit.

\subsection{Tourist satisfaction}

Satisfaction with tourism is one of the first competitive sources for tourism destinations (Sun, Geng-Qing Chi and $\mathrm{Xu}, 2013)$. Phillips et al., (2013) assert that the most prevalent aspect in tourism marketing is visitor satisfaction. This is an important factor in the marketing of destinations and support strategies and affects tourists' choice of destination and purposes .(Yoon and Uysal, 2005). The first component and component for assessing the performance of the destination should therefore be tourist satisfaction (Agyeiwaah et al., 2016).

The satisfaction and behavioral intentions of tourists are critical to success on the tourist front (Eusébio and Vieira, 2013). Therefore, focusing on behavioral intentions after a visit is very important because, according to the theory of logical behavior, it is an indicator of real behavior. From a cognitive standpoint, the idea of customer satisfaction can be viewed as a post-market evaluation that satisfies previous demands (Ajzen, 1991).

Also, tourist satisfaction affects WOM and the ability to make specific decisions and increases the intention to revisit the destination (de Matos and Rossi, 2008). therefore, suggested a relation between tourist desire and satisfaction the to make recommendations. usually, satisfaction leads to repetition and recommendation. In general, satisfaction leads to repetition and recommendation. A satisfied tourist enhances the effect and reliability higher than traditional advertising (Assaker and Hallak, 2013; Hong and Yang, 2009). Also, this online communication has been expanded (Chen and Chen, 2010). Keep in mind that the effects of tourist satisfaction on e-WOM may be more pronounced in the online environment due to the great strength travelers enjoy when using the internet to transmit feelings (de Matos and Rossi, 2008).

Previous studies concluded that this happiness of tourists has a positive effect on the potential visitors' behavior intention (Chen and Chen, 2010; Hutchinson, Wang and Lai, 2010; Kani et al., 2017). In general, tourist satisfaction has a big effect on the decision to revisit the USA (Hutchinson, Wang and Lai, 2010). This ensures that happy tourists recommend their friends and family to the same destination more frequently, they are more likely to visit (Sun, Geng-Qing Chi and Xu, 2013). Finally, (Kani et al., 2017) underlined that tourists' satisfaction has an effect on the e-WOM programmed. The following are the 8 and 9 hypotheses of this study:

H8: Tourist satisfaction has a direct and positive effect on e-WOM.

H9: Tourist satisfaction has a direct and positive effect on the tourists' intention to revisit.

\section{Methodology: Questionnaire Development and Measurements}

The questionnaire is designed to collect and verify data. Two main parts are part of the final plan. The first segment includes demographic features of tourists, such as gender, age, education, occupation and experience.

The Consists last part of the questionnaire of studied measures (items), selected based on the existing standards that have been certified or modified from previous studies (Table 1). To suit the current study, the indicators were slightly changed. It has also been measured by (6 items). Perceived behavior management ( 3 items) Arbitrary expectations ( 3 items), e-WOM (5 items), tourist satisfaction (4 items) and intention re-visit (4 items). 5-point indicative differential scale, all other combinations were evaluated using Likert 5-point scale (five points for Strongly agree - four points for Agree - three points for Neutral- two points for Disagree - and finally one point for Strongly Disagree)

The model had been first tested before the test by a committee of two academic members specializing in content verification. Then recommended the test based on existing information indicating the presence of many tourists visiting Luxor and Aswan during the study period. The questionnaire was prepared in English and ties and tests of reliability verified the integrity of the house. Since the total corrected correlation loads were between 0.36 and 0.82 , all elements were chosen. Cronbach latency also exceeds the recommended value of 0.75 and is between 0.77 and 0.93 .

The sources of the items that were used in the scales are shown in the following table 1:- 
Table 1. Items and sources of the study's questionnaire

\begin{tabular}{|c|c|c|}
\hline Construct & Measurement Items & Source \\
\hline $\begin{array}{l}\text { 1. Attitude toward } \\
\text { revisiting Luxor and } \\
\text { Aswan. }\end{array}$ & $\begin{array}{l}\text { ATT1. For me, revisiting Luxor and Aswan for } \\
\text { travel is extremely enjoyable. } \\
\text { ATT2. For me, revisiting Luxor and Aswan for } \\
\text { travel is extremely pleasant. } \\
\text { ATT3. For me, revisiting Luxor and Aswan for } \\
\text { travel is Extremely interesting. } \\
\text { ATT4. For me, revisiting Luxor and Aswan for } \\
\text { travel is extremely satisfactory. } \\
\text { ATT5. For me, revisiting Luxor and Aswan for } \\
\text { travel is extremely worthwhile. } \\
\text { ATT6. For me, revisiting Luxor and Aswan for } \\
\text { travel is extremely favorable. }\end{array}$ & $\begin{array}{l}\text { (Han, Hsu and Sheu, } \\
\text { 2010; Cheng, Lam and } \\
\text { Hsu, 2006b) }\end{array}$ \\
\hline 2. Subjective norms. & $\begin{array}{l}\text { SN1. In the near future most people important to } \\
\text { me think that I should revisit Luxor and Aswan. } \\
\text { SN2. In the near future most people who are } \\
\text { important to me would want me to revisit Luxor } \\
\text { and Aswan. } \\
\text { SN3. In the near future people whose opinions are } \\
\text { valued to me would prefer that I should revisit } \\
\text { Luxor and Aswan. }\end{array}$ & $\begin{array}{l}\text { (Han, Hsu and Sheu, } \\
\text { 2010; Huang and Hsu, } \\
\text { 2009) }\end{array}$ \\
\hline $\begin{array}{ll}\text { 3. } & \begin{array}{l}\text { Perceived } \\
\text { behavioral control. }\end{array}\end{array}$ & $\begin{array}{l}\text { PBC1. In the near future Whether or not I revisit } \\
\text { Luxor and Aswan is completely up to me. } \\
\text { PBC2. I am confident that I can revisit Luxor and } \\
\text { Aswan. } \\
\text { PBC3. In the near future Whether or not I revisit } \\
\text { Egypt is completely up to me. I have money to } \\
\text { revisit Luxor and Aswan. }\end{array}$ & $\begin{array}{l}\text { (Huang and Hsu, } \\
\text { 2009; Cheng, Lam and } \\
\text { Hsu, 2006b) }\end{array}$ \\
\hline $\begin{array}{l}\text { 4. Electronic word of } \\
\text { mouth. }\end{array}$ & $\begin{array}{l}\text { e-WOM1. To make sure I select the correct } \\
\text { destination, I read other tourists' online travel } \\
\text { reviews. } \\
\text { e-WOM2. I consult other travelers' online travel } \\
\text { reviews to aid select an attractive destination. } \\
\text { e-WOM3. I frequently gather information from } \\
\text { tourists' online travel reviews before I travel to } \\
\text { Luxor and Aswan. } \\
\text { e-WOM4. Tourists' online travel reviews make me } \\
\text { confident in traveling to Luxor and Aswan. }\end{array}$ & $\begin{array}{l}\text { (Jalilvand and Samiei, } \\
\text { 2012;Reza Jalilvand et } \\
\text { al., 2012) }\end{array}$ \\
\hline 5. tourist satisfaction. & $\begin{array}{l}\text { TS1.My visit to Luxor and Aswan was exactly } \\
\text { what I needed. } \\
\text { TS2.I am satisfied with my decision to visit Luxor } \\
\text { and Aswan. } \\
\text { TS3.I really enjoyed my visit to Luxor and Aswan. } \\
\text { TS4.Overall, I am satisfied with my visit to Luxor } \\
\text { and Aswan. }\end{array}$ & $\begin{array}{l}\text { (Sun, Geng-Qing Chi } \\
\text { and Xu, 2013;Kani et } \\
\text { al., 2017;Agyeiwaah et } \\
\text { al., 2016) }\end{array}$ \\
\hline 6. Revisit intention. & $\begin{array}{l}\text { RI1. In the near future, I tend to visit Luxor and } \\
\text { Aswan again. } \\
\text { RI2. In the near future I'd love to revisit Luxor and } \\
\text { Aswan again. } \\
\text { RI3 In the near future, I desire to revisit Luxor and } \\
\text { Aswan again. } \\
\text { RI4 In the near future I plan to revisit Luxor and } \\
\text { Aswan again. }\end{array}$ & $\begin{array}{l}\text { (Huang and Hsu, } \\
\text { 2009;Zhang, Wu and } \\
\text { Buhalis, 2018) }\end{array}$ \\
\hline
\end{tabular}

\section{Sampling and Data Collection}

This study includes the target population of local tourists who visited Luxor and Aswan before and data was collected online during the period from February 14, 2020 to May 23, 2020. This duration is also considered the height of the tourist season in Luxor and Aswan (CAPMAS, 2018) due to COVID 19 and the lack of detailed data 
on size and position of the array, the possible sampling techniques could not be used. Therefore, use comfort samples in this study. Social media participants were surveyed and online questionnaires such as Facebook, LinkedIn and Instagram were distributed. A total of 421 Tourists were collected and 373 retained. 373 answers were considered correct for further analysis following the removal of invalid templates. The ratio of approximately $80 \%$ is true. Form is deleted if missing values are present and 10 grades or more occur in sequence.

Firstly: Demographic profile

Table 2. Respondents Demographic profile.

\begin{tabular}{|c|c|c|c|}
\hline Variable & Classification & Frequency & Percent $(\%)$ \\
\hline \multirow{2}{*}{ Gender } & Female & 173 & 46.5 \\
\hline & Male & 199 & 53.5 \\
\hline \multirow{4}{*}{ Age } & Less than 20 & 27 & 7.3 \\
\hline & $20-30$ & 184 & 49.5 \\
\hline & $31-40$ & 83 & 22.3 \\
\hline & More than 41 & 78 & 21.0 \\
\hline \multirow{4}{*}{ Highest education level } & High school & 39 & 10.5 \\
\hline & University/college & 253 & 68.0 \\
\hline & Post graduate & 54 & 14.5 \\
\hline & Technical & 26 & 7.0 \\
\hline \multirow{4}{*}{ Status } & Single & 106 & 28.5 \\
\hline & In a relationship & 68 & 18.3 \\
\hline & Married & 174 & 46.8 \\
\hline & Divorced & 24 & 6.5 \\
\hline \multirow{4}{*}{ past experience } & Never & 19 & 5.1 \\
\hline & 1 Time & 94 & 25.3 \\
\hline & 2-3 Times & 159 & 42.7 \\
\hline & 4 or more & 100 & 26.9 \\
\hline Total & & 372 & 100.0 \\
\hline
\end{tabular}

The respondents have demographics shown. It shows that 199 were male and 173 were female and over $92.8 \%$ between 25 and 45 years of age. The majority had high levels of education, with $82,5 \%$ holding a university degree or higher degree. Status $28.5 \%$ single and $18.3 \%$ married and 6.5 percent divorced in a relationship and 46.8 percent. 5.1\% had no prior travel experience in Luxor and Aswan, while 94.6\% visited Luxor and Aswan before.

\section{Data analysis and results}

The present study used SEM-PLS modeling to enable the simultaneous evaluation of the measurement pattern and the structural model for analysis purposes (Marcoulides and Saunders, 2006). In addition, PLS is ideal for analyzing small samples. A two-phase approach was suggested to perform SEM and to determine whether the proposed search method is more suitable for use with data WarpPLS 6.0 and SPSS 26.0 (Anderson, Kellogg and Gerbing, 1988). To check the reliability of construction steps, the product of (external) measurement is provided. Furthermore, the assessment and evaluation of the causal link of the key variables identified within the measuring model for the structural (internal) model.

\section{Evaluation of the Measurement Model}

The most common way to test the measuring model in order to assess measurement internal accuracy is to calculate the alpha building coefficient. Table 2, which includes 20 metrics with six constructions, all the alpha Cronbach values tend to be greater than 0,70 . All measures therefore relate to reliability of the internal coherence (Nunnally, 1978) . Moreover, the combined security, which is extra suitable for PLS-SEM than Alpha Cronbach (Hair, Ringle and Sarstedt, 2011), Moreover, the combined reliability is more than the value of 0.70 suggested. In fact, the regular downloads of all metrics are above the values (Fornell and Larcker, 1981).

The converged validity of the building validation test was assessed, indicating the level of the measurement that could well reflect the variables studied. Designed to evaluate the variable itself. This convergent validity is evaluated, (AVE) was also used. As in Table 3, avers are greater than 0.55 . The validity of the consent is confirmed (Fornell and Larcker, 1981). The strength of the distinction demonstrates the degree to which the underlying variables are differentiated by influences. The discriminatory validity of testing whether the underlying variable is more strongly associated with its own elements with other structures was assessed by investigating contrast overlap by comparing (AVE) for each building with multi-square links between structures. If (AVE) meets the ties in all cases, discriminatory validity may be achieved. The square root for each structure (SQRTAVEs), which supports proof that the distinction is true, is greater than each connection's square value. Finally, the validity and reliability of the formulations tested have been achieved on the basis of the external model test. 
Secondly: the validity of the outer model

Table 3. Validity of the Outer Model

\begin{tabular}{|c|c|c|c|c|c|}
\hline constructs/indicators & $\begin{array}{l}\text { Cronbach's } \\
\text { Alpha }\end{array}$ & $\begin{array}{l}\text { Composite } \\
\text { Reliability }\end{array}$ & $\begin{array}{l}\text { standardized } \\
\text { loading }\end{array}$ & $\begin{array}{l}\text { Average } \\
\text { Extracted }\end{array}$ & Variance \\
\hline $\begin{array}{l}\text { Attitude toward revisiting Luxor } \\
\text { and Aswan }\end{array}$ & 0.933 & 0.8835 & & 0.5596 & \\
\hline First ATT & & & 0.675 & & \\
\hline Second ATT & & & 0.7314 & & \\
\hline Third ATT & & & 0.7223 & & \\
\hline Fourth ATT & & & 0.7506 & & \\
\hline Fifth ATT & & & 0.8593 & & \\
\hline Sixth ATT & & & 0.7374 & & \\
\hline Electronic word of mouth & 0.939 & 0.8207 & & 0.5342 & \\
\hline First EWOM & & & 0.75 & & \\
\hline Second EWOM & & & 0.7012 & & \\
\hline Third EWOM & & & 0.7737 & & \\
\hline Fourth EWOM & & & 0.6957 & & \\
\hline Perceived behavioral control & 0.858 & 0.7905 & & 0.558 & \\
\hline First PBC & & & 0.7996 & & \\
\hline Second PBC & & & 0.7532 & & \\
\hline Third PBC & & & 0.6837 & & \\
\hline Revisit intention & 0.953 & 0.8616 & & 0.6093 & \\
\hline First RI & & & 0.7212 & & \\
\hline Second RI & & & 0.7984 & & \\
\hline Third RI & & & 0.7937 & & \\
\hline Fourth RI & & & 0.8059 & & \\
\hline Subjective norms & 0.898 & 0.8011 & & 0.5734 & \\
\hline First SN & & & 0.7748 & & \\
\hline Second SN & & & 0.7192 & & \\
\hline Third SN & & & 0.7763 & & \\
\hline tourist satisfaction & 0.939 & 0.831 & & 0.5516 & \\
\hline First TS & \multirow{4}{*}{$\begin{array}{l}\text { Cronbach's } \\
\text { Alpha }\end{array}$} & \multirow{4}{*}{$\begin{array}{l}\text { Composite } \\
\text { Reliability }\end{array}$} & 0.7078 & \multirow{4}{*}{$\begin{array}{l}\text { Average } \\
\text { Extracted }\end{array}$} & \multirow{4}{*}{ Variance } \\
\hline Second TS & & & 0.7486 & & \\
\hline Third TS & & & 0.7567 & & \\
\hline Fourth TS & & & 0.7567 & & \\
\hline
\end{tabular}

Thirdly: Discriminant Validity-Correlations between Latent Variables

Table 4. Discriminant validity (Correlations between Latent Variables).

Numbers between brackets represent SQRT AVES.

\begin{tabular}{|c|c|c|c|c|c|c|}
\hline & 1 & 2 & 3 & 4 & 5 & 6 \\
\hline $\begin{array}{c}\text { 1.Attitude toward revisiting Luxor } \\
\text { and Aswan }\end{array}$ & $(0.748)$ & & & & & \\
\hline 2.Subjective norms & 0.818 & $(0.731)$ & & & & \\
\hline 3.Perceived behavioral control & 0.805 & 0.855 & $(0.747)$ & & & \\
\hline 4.Electronic word of mouth & 0.746 & 0.748 & 0.789 & $(0.780)$ & & \\
\hline 5.tourist satisfaction & 0.788 & 0.744 & 0.747 & 0.822 & $(0.757)$ & \\
\hline 6.Revisit intention & 0.726 & 0.7 & 0.716 & 0.763 & 0.895 & $(0.743)$ \\
\hline
\end{tabular}


Figure 2: SmartPLS output (PLS Algorithm (Path coefficients, R2, item loadings)

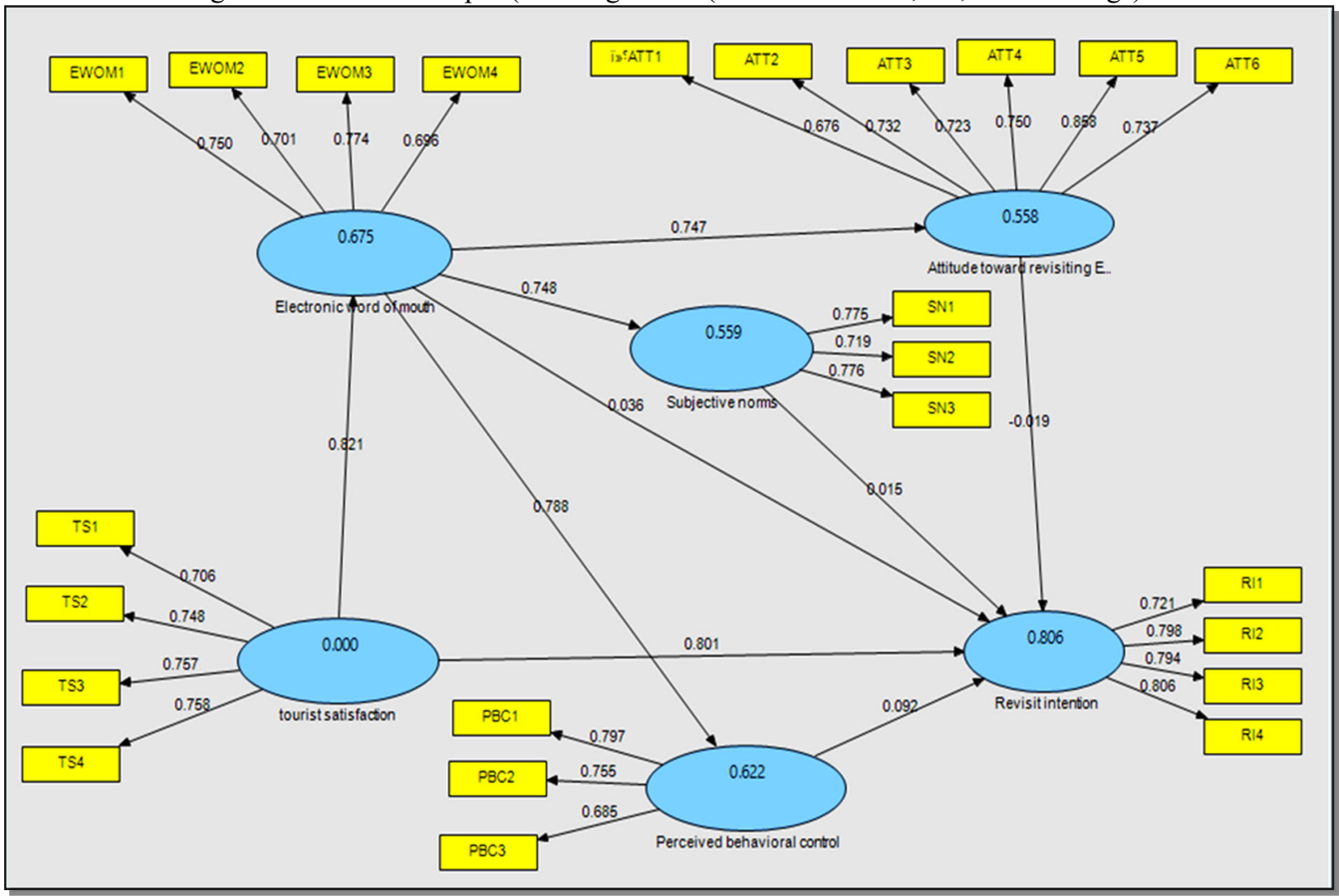

The next step in the analysis is to measure the hypothetical correlations between underlying variables by significance levels (P) ((Hair, Ringle and Sarstedt, 2011).

\begin{tabular}{|c|c|c|c|c|c|}
\hline Typothesis & independent variable & & Dependent variable & Coefficients & $p$ value \\
\hline H1 & E-WOM & $----->$ & ATT & 0.747 & 0.001 \\
\hline H2 & E-WOM & $---->>$ & SN & 0.748 & 0.001 \\
\hline H3 & E-WOM & $---->$ & PBC & 0.788 & 0.001 \\
\hline H4 & ATT & $---->$ & RI & -0.0195 & 0.714 \\
\hline H5 & SN & $---->$ & RI & 0.015 & 0.738 \\
\hline H6 & PBC & $---->$ & RI & 0.092 & 0.013 \\
\hline H7 & E-WOM & $---->$ & RI & 0.036 & 0.582 \\
\hline H8 & TS & $---->>$ & E-WOM & 0.821 & 0.001 \\
\hline H9 & TS & RI & 0.801 & 0.001 \\
\hline
\end{tabular}

From the previous table we can see that

- There is significant effect $(p$ value $=0.001<0.05)$ for electronic word of mouth on attitude toward revisiting Luxor and Aswan where the Coefficient $=0.747$ which means that "when electronic word of mouth increase by one unit the attitude toward revisiting Luxor and Aswan will increase by 0.747 unit"

- There is significant effect $(p$ value $=0.001<0.05$ ) for electronic word of mouth on Subjective norms where the Coefficient $=0.748$ which means that "when electronic word of mouth increase by one unit the Subjective norms will increase by 0.748 unit"

- There is significant effect ( $\mathrm{p}$ value $=0.001<0.05$ ) for electronic word of mouth on Perceived behavioral control where the Coefficient $=0.788$ which means that "when electronic word of mouth increase by one unit the Perceived behavioral control will increase by 0.788 unit"

- $\quad$ There is no significant effect ( $\mathrm{p}$ value $=0.714>0.05$ ) for attitude toward revisiting Luxor and Aswan on revisit intention.

- $\quad$ There is no significant effect ( $p$ value $=0.738>0.05$ ) for subjective norms on revisit intention.

- There is significant effect ( $\mathrm{p}$ value $=0.013<0.05$ ) for Perceived behavioral control on revisit intention where the Coefficient $=0.092$ which means that "when the Perceived behavioral control increase by one unit the revisit intention will increase by 0.092 unit"

- $\quad$ There is no significant effect ( $p$ value $=0.582>0.05$ ) for electronic word of mouth on revisit intention.

- There is significant effect $(p$ value $=0.001<0.05$ ) for tourist satisfaction on electronic word of mouth 
where the Coefficient $=0.821$ which means that "when the tourist satisfaction increases by one unit the electronic word of mouth will increase by 0.821 unit"

- There is significant effect $(\mathrm{p}$ value $=0.001<0.05)$ for tourist satisfaction on revisit intention where the Coefficient $=0.801$ which means that "when the tourist satisfaction increase by one unit the revisit intention will increase by 0.801 unit"

In order to better understand the effects chain that leads to something, study of the mediation effect is important (Kenny, 2008). As a result, an examination of the indirect effect of the revisit intention was carried out on the intermediate roles, subjective criteria, perceived behavioral control, e-WOM. The results Table 4 Based on the Warp-PLS programme, e-WOM does not matter if it revisits intention. Furthermore, the desire to visit has an effect on tourist satisfaction. Finally, the results show that the interaction between e-WOM and revisit intention has not played a significant role.

\section{Results summary: -}

Table 6: Summary of Results

\begin{tabular}{|c|c|c|c|c|}
\hline Hypothesis & independent variable & & Dependent variable & Decision \\
\hline $\mathrm{H} 1$ & E-WOM & $---->>$ & ATT & accepted \\
\hline $\mathrm{H} 2$ & E-WOM & $----->$ & SN & accepted \\
\hline H3 & E-WOM & $----->$ & PBC & accepted \\
\hline $\mathrm{H} 4$ & ATT & $----->$ & RI & rejected \\
\hline H5 & SN & $----->$ & RI & rejected \\
\hline H6 & PBC & $----->$ & RI & accepted \\
\hline $\mathrm{H} 7$ & E-WOM & $----->$ & RI & rejected \\
\hline $\mathrm{H} 8$ & TS & $----->$ & E-WOM & accepted \\
\hline $\mathrm{H} 9$ & TS & $----->$ & RI & accepted \\
\hline
\end{tabular}

\section{Conclusion}

The goal of this study is to better understand the intention of revisiting Luxor and Aswan as destinations for tourists alike. Specifically, the amended model includes subjective standards, attitudes, perceived behavior controls and certain critical factors in tourism and compartmental literature, e.g., tourism satisfaction and e-WOM, in the original TPB structures. The structures analyzed were consistent, and for their underlying variable the dimension from previous studies.

The results show that the intention for tourists to revisit Luxor and Aswan was negatively influenced by the attitudes and subjective standards. Such results are consistent with previous studies (Han, Hsu and Sheu, 2010; Han and Kim, 2010; Hsu and Huang, 2012; Lam and Hsu, 2004; Cheng, Lam and Hsu, 2006b), The findings suggest, however, that behavioral influence perceived have positive and important effects on the intention of tourists to evaluate Luxor and Aswan. In other words, the revisits by local tourists were very positive and strongly linked to Luxor and Aswan 's optimistic perceived behavioral regulation.

The results indicate that e-WOM influences visitor behavior in a constructive and important manner. The previous results show the new e-WOM effect as tourist destination for Luxor and Aswan. The information published focuses on the positive aspects that will improve the reputation of Luxor and Aswan as a tourist destination. This creates a positive e-WOM that in turn affects the position of tourists. This would lead to positive e-WOM attitudes towards a certain product being increased (Jalilvand and Samiei, 2012; Lai Ying and Chung, 2007). E-WOM is also affected by subjective standards. The findings are in accordance with earlier research (Jalilvand and Samiei, 2012) The results showed, too, that the perceived behavioral control was negatively influenced. Studies (Jalilvand and Samiei, 2012; Lai Ying and Chung, 2007), were sponsored, where similar findings were also found. It indicates that e-WOM has a beneficial effect on behavior regulation that is perceived.

Furthermore, the findings showed that e-WOM adversely impact the revisit. It also indicates that e-WOM has negative effects, in particular on social media, on Luxor and Aswan as a destination. The findings are consistent with the previous studies (Jalilvand and Samiei, 2012) which showed that e-WOM was significantly influenced by the purpose of the study and the choice of destination.

\section{Theoretical and practical contributions}

Both scientific and practical outputs were investigated in this study. Initially, the results showed the benefit of eWOM on the TPB model. Also, the benefit of tourist satisfaction showed the prediction of the intention to revisit of a travel destination among local Tourists and e-WOM, which is recommended by relatives and friends as causal factors that influence travel decisions; Finally, structures can be used for various behaviors in various settings (Ajzen, 1991). In particular, the underlying variables (tourist satisfaction, e-WOM) included in the current analysis. The research itself makes a significant theoretical contribution to this article. This study has shown that the TPBs in a developing country of Egypt are important in comparison to the most popular models in the developed 
countries.

This study offers great insight into the planning and performance growth of destination management organizations in Luxor and Aswan regarding experimental contributions. It indicates that identifying the key factors that influence Tourists ' intention to visit or to recommend a destination will help to build successful marketing campaigns that encourage positive travel choices. The present study shows that the satisfaction of tourists and their behavior management are positively correlated with the intention of revisiting them. e-WOM was also found to have good TPB partnerships.

Therefore, Egyptian tourism vendors and tourist companies would reflect on improvements in these marketing strategies. The prediction and awareness of the drivers of journeys is necessary to create demand and facilitate decision-making. With sufficient awareness and understanding of travel behaviour, direct marketing organizations will also be able to establish and enforce effective tourism demand policies in Egypt. Tourism marketing strategies should be used by marketers and managers to increase the perceived incentive level for travelers. They should also send local tourists a direct assurance that the destination should meet their requirements. The present report showed that marketers should develop effective strategies to enhance the image of tourists through multiple information sources to disseminate the positive aspects of their destination.

The study revealed finally that e-WOM had a negative effect on the intention to revisit. In this context, the importance that e-WOM tourists place and why they are looking for guidance on virtual opinion platforms when making travel decisions is important to understand. Despite this, the media in Egypt need to concentrate its attention on the transport and publishing of a good image of the tourist destination Luxor and Aswan. Sensitivity campaigns also need to be organized via social media (Twitter, Facebook, LinkedIn, etc.), So that Luxor and Aswan can be viewed as a healthy and unique tourist destination. The role of familiar flights in enhancing e-WOM, destination and reputation should also be given special attention.

\section{Limitation and Future Research}

The present research must take strong limitations into account. Statistics have been obtained for Tourists in Luxor and Aswan. Future experiments at various locations should apply this trend to the impact of the facilities tested on tourist destination visits. In contrast with other destinations and traveler markets the conceptual model should be tested in specific studies. In addition, this study has expanded the TPB-model including some variables. A wider range of variables should then be included in the framework (for example, past conduct, customer loyalty, confidence in the location, perceived value, perceived risk, and personal features). The current study also restricted the use of online surveys by domestic tourists to gather data from respondents. In future studies a more extensive survey method should be used and sampled by international tourists. The present study focused exclusively on local tourists perceptions, which most tourists were not aware of, so future research could compare perceptions of international and domestic tourists as international tourists are growing in importance for traveling and tourism (Ragab, Mahrous and Ghoneim, 2019). Visitors with actual visitors (Stylidis and Cherifi, 2018) finally, The study focused primarily on behavioral intentions of actions. Goal to revisit. Future research may try negative intentions in the future, such as going to a different location with negative words of mouth.

\section{References}

Abubakar, A. M. et al. (2017) "eWOM, revisit intention, destination trust and gender," Journal of Hospitality and Tourism Management. Elsevier Ltd, 31, pp. 220-227. doi: 10.1016/j.jhtm.2016.12.005.

Abubakar, A. M., Ilkan, M. \& Sahin, P. (2016) "eWOM, eReferral and gender in the virtual community," Marketing Intelligence and Planning. Emerald Group Publishing Ltd., 34(5), pp. 692-710. doi: 10.1108/MIP05-2015-0090.

Agyeiwaah, E. et al. (2016) "Make a customer, not a sale: Tourist satisfaction in Hong Kong," Tourism Management. Elsevier Ltd, 57, pp. 68-79. doi: 10.1016/j.tourman.2016.05.014.

Ajzen, I. \& Fishbein, M. (1980) Understanding attitudes and predicting social behavior. Prentice-Hall.

Ajzen, I. \& Madden, T. J. (1986) "Prediction of goal-directed behavior: Attitudes, intentions, and perceived behavioral control," Journal of Experimental Social Psychology. Academic Press, 22(5), pp. 453-474. doi: 10.1016/0022-1031(86)90045-4.

Ajzen, I. (1991) "The theory of planned behavior," Organizational Behavior and Human Decision Processes. Academic Press, 50(2), pp. 179-211. doi: 10.1016/0749-5978(91)90020-T.

Anderson, J. C., Kellogg, J. L. \& Gerbing, D. W. (1988) Structural Equation Modeling in Practice: A Review and Recommended Two-Step Approach, Psychological Bulletin.

Assaker, G. \& Hallak, R. (2013) "Moderating Effects of Tourists' Novelty-Seeking Tendencies on Destination Image, Visitor Satisfaction, and Short- and Long-Term Revisit Intentions," Journal of Travel Research. SAGE Publications Ltd, 52(5), pp. 600-613. doi: 10.1177/0047287513478497.

Avraham, E. (2016) "Destination marketing and image repair during tourism crises: The case of Egypt," Journal of Hospitality and Tourism Management. Elsevier Ltd, 28, pp. 41-48. doi: 10.1016/j.jhtm.2016.04.004. 
Baber, A. et al. (2016) "Online word-of-mouth antecedents, attitude and intention-to-purchase electronic products in Pakistan," Telematics and Informatics. Elsevier Ltd, 33(2), pp. 388-400. doi: 10.1016/j.tele.2015.09.004.

Bianchi, C., Milberg, S. \& Cúneo, A. (2017) "Understanding travelers' intentions to visit a short versus long-haul emerging vacation destination: The case of Chile," Tourism Management. Elsevier Ltd, 59, pp. 312-324. doi: 10.1016/j.tourman.2016.08.013.

CAPMAS. (2018). Egypt in figures. Central Agency for Public Mobilization and Statistics. Retrieved from Egypt.

Castro, C. B., Martín Armario, E. \& Martín Ruiz, D. (2007) "The influence of market heterogeneity on the relationship between a destination's image and tourists' future behaviour," Tourism Management. Pergamon, 28(1), pp. 175-187. doi: 10.1016/j.tourman.2005.11.013.

Chen, C. F. \& Chen, F. S. (2010) "Experience quality, perceived value, satisfaction and behavioral intentions for heritage tourists," Tourism Management. Pergamon, 31(1), pp. 29-35. doi: 10.1016/j.tourman.2009.02.008.

Chen, M. F. \& Tung, P. J. (2014) "Developing an extended Theory of Planned Behavior model to predict consumers' intention to visit green hotels," International Journal of Hospitality Management, 36, pp. 221230. doi: 10.1016/j.ijhm.2013.09.006.

Cheng, S., Lam, T. \& Hsu, C. H. C. (2006a) "Negative Word-of-Mouth Communication Intention: An Application of the Theory of Planned Behavior," Journal of Hospitality \& Tourism Research. SAGE Publications Inc., 30(1), pp. 95-116. doi: 10.1177/1096348005284269.

Cheng, S., Lam, T. \& Hsu, C. H. C. (2006b) “Negative Word-of-Mouth Communication Intention: An Application of the Theory of Planned Behavior," Journal of Hospitality \& Tourism Research. SAGE Publications Inc., 30(1), pp. 95-116. doi: 10.1177/1096348005284269.

Cheung, C. M. K. \& Lee, M. K. O. (2012) "What drives consumers to spread electronic word of mouth in online consumer-opinion platforms," Decision Support Systems. Elsevier B.V., 53(1), pp. 218-225. doi: 10.1016/j.dss.2012.01.015.

de Matos, C. A. \& Rossi, C. A. V. (2008) "Word-of-mouth communications in marketing: A meta-analytic review of the antecedents and moderators," Journal of the Academy of Marketing Science. Springer, 36(4), pp. 578596. doi: 10.1007/s11747-008-0121-1.

Eusébio, C. \& Vieira, A. L. (2013) “Destination Attributes' Evaluation, Satisfaction and Behavioural Intentions: A Structural Modelling Approach," International Journal of Tourism Research, 15(1), pp. 66-80. doi: $10.1002 /$ jtr.877.

Fornell, C. \& Larcker, D. F. (1981) "Evaluating Structural Equation Models with Unobservable Variables and Measurement Error,” Journal of Marketing Research. JSTOR, 18(1), p. 39. doi: 10.2307/3151312.

Forum, W. E. (2019) The Travel and Tourism Competitiveness Report 2019. Available at: http://www3.weforum.org/docs/WEF TTCR 2019.pdf.

Hair, J. F., Ringle, C. M. \& Sarstedt, M. (2011) "PLS-SEM: Indeed, a silver bullet," Journal of Marketing Theory and Practice. M.E. Sharpe Inc., 19(2), pp. 139-152. doi: 10.2753/MTP1069-6679190202.

Han, H. \& Kim, Y. (2010) “An investigation of green hotel customers' decision formation: Developing an extended model of the theory of planned behavior," International Journal of Hospitality Management, 29(4), pp. 659-668. doi: 10.1016/j.ijhm.2010.01.001.

Han, H., Hsu, L. T. (Jane) \& Sheu, C. (2010) "Application of the Theory of Planned Behavior to green hotel choice: Testing the effect of environmentally friendly activities," Tourism Management. Pergamon, 31(3), pp. 325334. doi: 10.1016/j.tourman.2009.03.013.

Hong, S. Y. \& Yang, S. U. (2009) "Effects of reputation, relational satisfaction, and customer-company identification on positive word-of-mouth intentions," Journal of Public Relations Research. Taylor \& Francis Group , 21(4), pp. 381-403. doi: 10.1080/10627260902966433.

Hsu, C. H. C. \& Huang, S. (Sam) (2012) "An Extension of the Theory of Planned Behavior Model for Tourists," Journal of Hospitality \& Tourism Research. SAGE PublicationsSage CA: Los Angeles, CA, 36(3), pp. 390417. doi: $10.1177 / 1096348010390817$.

Huang, S. \& Hsu, C. H. C. (2009) "Effects of travel motivation, past experience, perceived constraint, and attitude on revisit intention," Journal of Travel Research. SAGE Publications Ltd, 48(1), pp. 29-44. doi: 10.1177/0047287508328793.

Hutchinson, J., Wang, Y. \& Lai, F. (2010) "The impact of satisfaction judgment on behavioral intentions: An investigation of golf travelers," Journal of Vacation Marketing, 16(1), pp. 45-59. doi: $10.1177 / 1356766709356203$.

Jalilvand, M. R. \& Samiei, N. (2012) "The impact of electronic word of mouth on a tourism destination choice: Testing the theory of planned behavior (TPB)," Internet Research. Emerald Group Publishing Limited, 22(5), pp. 591-612. doi: 10.1108/10662241211271563.

Jalilvand, M. R., Ebrahimi, A. \& Samiei, N. (2013) “Electronic Word of Mouth Effects on Tourists' Attitudes Toward Islamic Destinations and Travel Intention: An Empirical Study in Iran," Procedia - Social and Behavioral Sciences. Elsevier BV, 81, pp. 484-489. doi: 10.1016/j.sbspro.2013.06.465. 
Kamar, G. M. A. M. (2014) “The development of Luxor open air museum and its social impacts : an assessment using geographic information systems." University of Leicester.

Kani, Y. et al. (2017) “Antecedents and outcomes of destination image of Malaysia," Journal of Hospitality \&Tourism Management. Elsevier Ltd, 32, pp. 89-98. doi: 10.1016/j.jhtm.2017.05.001.

Kenny, D. A. (2008) "Reflections on mediation," Organizational Research Methods, 11(2), pp. 353-358. doi: $10.1177 / 1094428107308978$.

Ladhari, R. \&Michaud, M. (2015) "EWOM effects on hotel booking intentions, attitudes, trust, and website perceptions," International Journal of Hospitality Management. Elsevier Ltd, 46, pp. 36-45. doi: 10.1016/j.ijhm.2015.01.010.

Lai Ying, ho \& Chung, C. M. y. (2007) "The effects of single-message single-source mixed word-of-mouth on product attitude and purchase intention," Asia Pacific Journal of Marketing and Logistics. Emerald Group Publishing Limited, 19(1), pp. 75-86. doi: 10.1108/13555850710720911.

Lam, T. \& Hsu, C. H. C. (2004) "Theory of Planned Behavior: Potential Travelers from China," Journal of Hospitality \& Tourism Research. SAGE Publications Inc., 28(4), pp. 463-482. doi: $10.1177 / 1096348004267515$.

Lee, J., Park, D. H. \& Han, I. (2008) "The effect of negative online consumer reviews on product attitude: An information processing view," Electronic Commerce Research and Applications, 7(3), pp. 341-352. doi: 10.1016/j.elerap.2007.05.004.

Litvin, S. W., Goldsmith, R. E. \& Pan, B. (2008) "Electronic word-of-mouth in hospitality and tourism management," Tourism Management, 29(3), pp. 458-468. doi: 10.1016/j.tourman.2007.05.011.

Liu, C. H. S. \& Lee, T. (2016) "Service quality and price perception of service: Influence on word-of-mouth and revisit intention," Journal of Air Transport Management. Elsevier Ltd, 52, pp. 42-54. doi: 10.1016/j.jairtraman.2015.12.007.

Luo, Q. \& Zhong, D. (2015) "Using social network analysis to explain communication characteristics of travelrelated electronic word-of-mouth on social networking sites," Tourism Management. Elsevier Ltd, 46, pp. 274-282. doi: 10.1016/j.tourman.2014.07.007.

Marcoulides, G. A. \& Saunders, C. (2006) "PLS: A silver bullet?” MIS Quarterly: Management Information Systems. University of Minnesota, p. iii. doi: 10.2307/25148727.

Matute, J., Polo-Redondo, Y. \& Utrillas, A. (2016) "The influence of EWOM characteristics on online repurchase intention: Mediating roles of trust and perceived usefulness," Online Information Review. Emerald Group Publishing Ltd., 40(7), pp. 1090-1110. doi: 10.1108/OIR-11-2015-0373.

Moutinho, L., Ballantyne, R. \& Rate, S. (2011) "Consumer behaviour in tourism.” CABI, p. 5.

Nunnally, J. C. (1978) "Phychometric theory.," Psychometric theory, p. 640.

Palka, W., Pousttchi, K. \& Wiedemann, D. G. (2009) "Mobile word-of-mouth - A grounded theory of mobile viral marketing," Journal of Information Technology, 24(2), pp. 172-185. doi: 10.1057/jit.2008.37.

Phillips, W. J. et al. (2013) "Tourist Word of Mouth and Revisit Intentions to Rural Tourism Destinations: A Case of North Dakota, USA,” International Journal of Tourism Research, 15(1), pp. 93-104. doi: 10.1002/jtr.879.

Puad, A. et al. (2012) "Factors Influencing Visitors' Revisit Behavioral Intentions: A Case Study of Sabah, Malaysia," International Journal of Marketing Studies, 4(4). doi: 10.5539/ijms. v4n4p39.

Ragab, H., Mahrous, A. A. \& Ghoneim, A. (2019) "Egypt's perceived destination image and its impact on tourist's future behavioural intentions," International Journal of Tourism Cities. Emerald Group Publishing Ltd. doi: 10.1108/IJTC-12-2018-0105.

Reza Jalilvand, M. et al. (2012) "Examining the structural relationships of electronic word of mouth, destination image, tourist attitude toward destination and travel intention: An integrated approach," Journal of Destination Marketing and Management. Elsevier Ltd, 1(1-2), pp. 134-143. doi: 10.1016/j.jdmm.2012.10.001.

Stylidis, D. \& Cherifi, B. (2018) “Characteristics of destination image: visitors and non-visitors' images of London," Tourism Review. Emerald Group Publishing Ltd., 73(1), pp. 55-67. doi: 10.1108/TR-05-20170090

Sun, X., Geng-Qing Chi, C. \& Xu, H. (2013) "Developing destination loyalty: The case of hainan island," Annals of Tourism Research, 43, pp. 547-577. doi: 10.1016/j.annals.2013.04.006.

UNWTO Tourism highlights 2018 edition (2018). World Tourism Organization.

Verma, V. K. \& Chandra, B. (2018) “An application of theory of planned behavior to predict young Indian consumers' green hotel visit intention," Journal of Cleaner Production. Elsevier Ltd, 172, pp. 1152-1162. doi: 10.1016/j.jclepro.2017.10.047.

Yoon, Y. \& Uysal, M. (2005) "An examination of the effects of motivation and satisfaction on destination loyalty: A structural model," Tourism Management. Pergamon, 26(1), pp. 45-56. doi: 10.1016/j.tourman.2003.08.016.

Yuzhanin, S. \& Fisher, D. (2016) "The efficacy of the theory of planned behavior for predicting intentions to choose a travel destination: a review," Tourism Review. Emerald Group Publishing Ltd., pp. 135-147. doi: 
10.1108/TR-11-2015-0055.

Zhang, H., Wu, Y. \& Buhalis, D. (2018) "A model of perceived image, memorable tourism experiences and revisit intention," Journal of Destination Marketing and Management. Elsevier Ltd, 8, pp. 326-336. doi: 10.1016/j.jdmm.2017.06.004. 